\title{
Effect of Zamzam Water Extract of Curcuma zedoaria Treatment on Apoptosis, p53 and Bcl2 Protein Expression of T47D Cell Culture
}

\author{
Titiek Sumarawati ${ }^{1}$, Taufiqurrachman Nasihun ${ }^{2}$ and Chodidjah $^{3}$ \\ 'Department of Chemistry, Medical Faculty, Sultan Agung Islamic University, \\ Central Java - 50112, Indonesia \\ 2Department of Biochemistry, Sultan Agung Islamic University, Semarang, Central Java - 50112, Indonesia \\ ${ }^{3}$ Department of Anatomy, Medical Faculty, Sultan Agung Islamic University, Central Java - 50112, Indonesia
}

\begin{abstract}
Introduction: People worldwide drink Zamzam water either medicinally or religiously. However, the effect of zamzam water extract of $\mathrm{CZ}$ in breast cancer cells remains unclear. Objective: To evaluate the zamzam water extract of CZ effect on cell apoptosis, p53 and Bcl 2 protein expression in T47 D cells line culture. Methods: In the control group design, 16 Wells which was filled with T47 D cell line culture in the density of $5 \times 10^{4} / 100 \mu \mathrm{l}$, were assigned into 4 groups. Control group (C-G), were only filled with T47D cell line culture; Zamzam 50 (ZZ-50); Zamzam 100 (ZZ-100), and Zamzam 500 (ZZ-500) groups, were filled with T47D cell line cultures and 50,100, and $500 \mu \mathrm{g} / \mathrm{ml}$ zamzam water extract of CZ respectively, and then incubated for 48 hours. The number of apoptotic cell was counted by flow cytometry, while p53 and Bcl 2 measured by immunohistochemistry staining method. Results: Mann Whitney analysis indicated that the percentage of apoptotic cell and $p 53$ protein expression in ZZ-100 was significant higher compared to that of C-G $(p<0.05)$. In contrary the percentage number of $\mathrm{BC} / 2$ protein expression in ZZ100-G was significantly lower when compared to that of C-G $(p<0.05)$. Conclusion: Treatment of zamzam water extract of CZ on T47D cell line cultured was capable of increasing the number of apoptotic cells, p53 protein expression, but decreased Bcl2 protein expression in T47D cell line culture. However the numbers of apoptotic cells were less than $10 \%$.
\end{abstract}

Keywords: Apoptosis, Breast Cancer, Chemoprevention, Flavonoids, p53mutan

\section{Introduction}

Cancer is still considered as the most detrimental for survival of humans amongst different diseases ${ }^{1}$. In women, the second leading cause of cancer death across the world is breast cancer ${ }^{2,3}$. Fortunately, since two decades ago, incidence rate of breast cancer was decreased around $3.5 \%$ per year ${ }^{3}$. In that period, the mortality rate of breast cancer had also reduced to $24 \%$ particularly, on women with Estrogen-Progesterone Receptor positive cancer disease $\mathrm{e}^{4}$. The decrease in breast cancer mortality rate was attributable to the combination of early detection with screening programs and the efficacious adjuvant systemic therapy ${ }^{5}$. Flavonoids from plants are the most prominence chemical constituents that were widely used as adjuvant systemic therapy. Various studies have pointed out those flavonoids or flavonoid derivatives having pivotal roles in cancer chemoprevention and chemotherapy ${ }^{6}$. Some epidemiological studies indicate that high flavonoids intake may be associated with declining of cancer risk, and therefore can be proposed as a chemoprotective treatment against cancer ${ }^{6}$. Invitro studies also provide evidence that flavonoids may be associated with cell proliferation inhibition, adhesion, and invasion, inducing cell differentiation, cell cycle arrest, and apoptosis ${ }^{7}$. 
It is well known that Curcuma zedoaria (CZ) (Zingiberaceae) also known as white turmeric possess several active chemical components such as terpenoids, flavonoids, phenylpropanoids and sesquiterpenes. The medicinal properties of $\mathrm{CZ}$ depend upon the presence of these active chemical component ${ }^{8}$. The prominence medicinal properties of $\mathrm{CZ}$ includes cytotoxic, antimutagenic $c^{8,9}$, antitumor, antioxidant, antimicrobial, anti-inflammation, and antiangiogenesis activities ${ }^{9}$. In Indonesia Curcuma zedoaria (CZ) has been traditionally proven capable of inhibiting breast cancer cells progression invivo ${ }^{3}$. There are study reports that $\mathrm{CZ}$ containing isocurcumenol from ethanol extract is capable of inhibiting the proliferation, increased apoptosis and expression of caspase- 3 in cancer cells ${ }^{10}$. In addition, curzerenon and alismol from hexane fraction of $\mathrm{CZ}$ were able to inhibit the MCF7 proliferation and possess a cytotoxic effect in MCF7 cell culture ${ }^{11}$. Another study has also reported that treatment with $\mathrm{CZ}$ ethanol extraction at the dose of $300 \mathrm{mg} / \mathrm{kg}$ and 750 $\mathrm{mg} / \mathrm{kg}$ body weight (BW) has been proven to inhibit expression of $\mathrm{p} 53$ and $\mathrm{H}$-Ras in mutant mammary gland cells. Moreover, treatment of CZ extract is also capable of reducing the mammary gland tumor incidence in rats $^{12}$. Another study reported by Papademetrio DL, et al., (2013) indicated that flavonoid contained in CZ was able to induce apoptosis through decrease in $\mathrm{Bcl} 2$ expression and otherwise increase in expression ${ }^{13}$.

To date ethanol is an important organic solvent and substrate which is used extensively to extract flavonoids and polyphenol from plants ${ }^{14}$. There are growing evidences that $\mathrm{CZ}$ extraction with ethanol have capability killing cancer cells ${ }^{7}$. Unfortunately, ethanol has also been proved capable of inducing hemorrhagic gastric lesions, at least in part by increasing oxidative stress ${ }^{15}$. Therefore, natural water should be considered as an appropriate alternative solvent for this purpose. Aside from plain tap water, Zamzam water is a type of natural water obtained from well located in holy mosque in Mecca, Saudi Arabia have been consumed by millions of Muslims all over the world ${ }^{16,17}$. Based on Muslim religious beliefs zamzam water is holy and miraculous water therefore to be scientifically superior to plain tap water. Accordingly to many Muslims worldwide including people in Indonesia drink Zamzam water either medicinally or religiously ${ }^{17}$.
Based on phytochemistry analysis, zamzam water extract of CZ contained higher flavonoids, phenolic, and saponin content compared to that of plain tap water ${ }^{18}$. However, the effect of zamzam water extract of $\mathrm{CZ}$ remains unclear. In this study zamzam water was used to replace ethanol as a solvent for extraction of $\mathrm{CZ}$ and to measure the extracts effect on p53 and Bcl 2 expression, and apoptosis cells on T47D cell line cultured. T47D cell lines were selected because of an appropriate and ideal experimental model to elucidate the estrogen and progesterone-specific effects of a luminal A subtype of breast cancer ${ }^{19,20}$. In addition, some previous studies have also pointed out that T47Dcell line express p53 mutation, therefore unable to bind DNA and loss its capacity to regulates cell cycle, inhibit apoptosis, and hence serve as pro-survival in breast cancer ${ }^{21}$.

\section{Methods}

In experimental study, post test only control group design, 12 wells which was filled with culture of T47 D cell line in the density of $5 \times 10^{4} / 100 \mu$ were assigned into 4 groups, three wells of each consist of: Control group (C-G), was only filled with T47D cell line culture; Zamzam 50 (ZZ50-G), Zamzam 100 (ZZ100-G), and Zamzam 500 (ZZ500-G) groups, were filled with T47D cell line culture and treated with 50,100, and $500 \mu \mathrm{g} /$ $\mathrm{ml} \mathrm{CZ}$ diluted in Zamzam water respectively. All replications were then incubated at $37^{\circ} \mathrm{C}$ temperature in $\mathrm{CO}_{2}$ incubator during 48 hours. The number of cell apoptosis was analyzed by flow cytometry, while mutant p53 and Bcl2 expression were measured by immunohistochemistry method. The expression of p53 and $\mathrm{Bcl} 2$ were assessed under the light microscope with 400x magnification by the hot spot method. This study was approved by Ethics Committee of the Faculty of Medicine, Sultan Agung Islamic University Semarang.

\subsection{Curcuma zedoaria Extract}

Curcuma zedoaria (CZ) obtained from market was washed, sliced, air dried, and powdered. $200 \mathrm{~g}$ of dry powder of CZ was extracted by Soxhlet method with zamzam water as a solvent. Zamzam water boiling point is similar to other plain water $\left(100^{\circ} \mathrm{C}\right)$, however in this study zamzam waters boiling point was set at $80^{\circ} \mathrm{C}$ in order to extract all flavonid of CZ. The extract was 
concentrated using a rotary evaporator. The extraction process was carried out in the Chemical laboratory of Sultan Agung Islamic University Medical Faculty, Semarang, Central Java Indonesia.

\subsection{Immunohistochemistry Stained Slides Preparation for $\mathrm{p} 53$ and Bcl2 Protein Expression}

The immunohistochemical stained slides were prepared by deparaffining process for totally 110 minutes, then the slides were immersed in Mayer Hematoxylin stain for 6 minutes. It was washed in running water, dehydrated, cleared, and mounted.

\subsection{Analysis of Apoptotic Cells by Flow Cytometry}

Apoptosis T47D cells following the treatment with Curcuma zedoaria was dissolved in zamzam water was analyzed by flow cytometry FITC apoptosis detection kit with Propidium Iodide (Sigma-Aldrich). In this flow cytometry Annexin V was used to detect apoptosis cells by its ability to bind with phosphatidylserine located in the outer leaflet of the plasma membrane. In normal cell phosphatidylserine is hidden within plasma membrane, however during apoptosis phosphatidylserine is translocated from the cytoplasmic face of the plasma membrane to the cell surface as an endpoint indicator of early and late apoptosis.

\subsection{Statistical Analysis}

The total number of $\mathrm{p} 53$ and $\mathrm{Bcl} 2$ protein expression and cell apoptosis were presented as the mean \pm SD. Differences between groups were analyzed for statistical significance, using Anova and followed by Post Hoc LSD test with the significance level of $95 \%$.

\section{Results}

After 48 hours incubation at $37^{\circ} \mathrm{C}$ temperature in $\mathrm{CO}_{2}$ incubator, the total number of $\mathrm{p} 53$ and $\mathrm{Bcl} 2$ protein expression were assessed under the light microscope with 400x magnification by the hot spot method (Figure 1) whereas the apoptotic cells were analyzed with flow cytometry (Figure 2). The mean of total number of protein p53 and $\mathrm{Bcl} 2$ expression, apoptosis and necrotic cells are presented in Table 1.

The expression of $\mathrm{p} 53$ protein was highest in ZZ100-G, followed by ZZ50-G, ZZ500-G, and the lowest was in C-G and ZZ500-G. In contrary, the highest expression of Bcl2 protein was in C-G. Followed by ZZ50-G, ZZ500-G, and the lowest was in ZZ100-G. Since the data of p53 percentage was abnormal, nonparametric test Kurskall Wallis was used. On the other hand considering the data in number of $\mathrm{Bcl} 2$ protein expression percentage was normal distribution, therefore data was analyzed used Anova. Both of Kurskall Wallis and Anova analysis indicated that there were significant differences among groups, $\mathrm{p}<0.05$ (Figure 1 ).

Apoptotic cells were measured by flow cytometry which showed that the highest apoptotis was in ZZ500-G, followed by ZZ100-G, ZZ50-G, and the lowest was in C-G. Kurskalwallis statistical analysis on the percentage of apoptotic cells indicated that there were significant differences among groups, $\mathrm{p}<0.05$ (Figure 2).

In order to identify which one of the $\mathrm{p} 53, \mathrm{Bcl} 2$ protein expression and apoptosis cell group possessed significant difference between two groups were studied further.

Table 1. Total Number of $\mathrm{p} 53$ and Bcl2 Protein expression, and apoptosis Cells

\begin{tabular}{llccc}
\multicolumn{1}{c}{ Variables } & \multicolumn{3}{c}{ Groups } \\
\cline { 2 - 5 } & \multicolumn{1}{c}{$\begin{array}{c}\text { C-G } \\
(\mathbf{n}=5) \chi( \pm)\end{array}$} & $\begin{array}{r}\text { ZZ50-G } \\
(\mathbf{n}=5) \chi( \pm)\end{array}$ & $\begin{array}{r}\text { ZZ100-G } \\
(\mathbf{n}=5) \chi( \pm)\end{array}$ & $\begin{array}{c}\text { ZZ500-G } \\
(\mathbf{n}=5) \chi( \pm)\end{array}$ \\
\hline P53 Expression (\%) & $10( \pm 0.70)$ & $12( \pm 0.70)$ & $14( \pm 0.70)$ & $10( \pm 0.70)$ \\
Bcl2 Expression (\%) & $40( \pm 0.70)$ & $39( \pm 0.70)$ & $37( \pm 0.70)$ & $38( \pm 0.70)$ \\
Apoptotic Cells (\%) & $4.01( \pm 0.12)$ & $3.67( \pm 0,06)$ & $5.16( \pm 0,12)$ & $8.87( \pm 0,23)$ \\
Survival Cells (\%) & $94.67(+0.29)$ & $95.55( \pm 0.05)$ & $95.33( \pm 0.09)$ & $90.91( \pm 0.20)$ \\
\hline
\end{tabular}



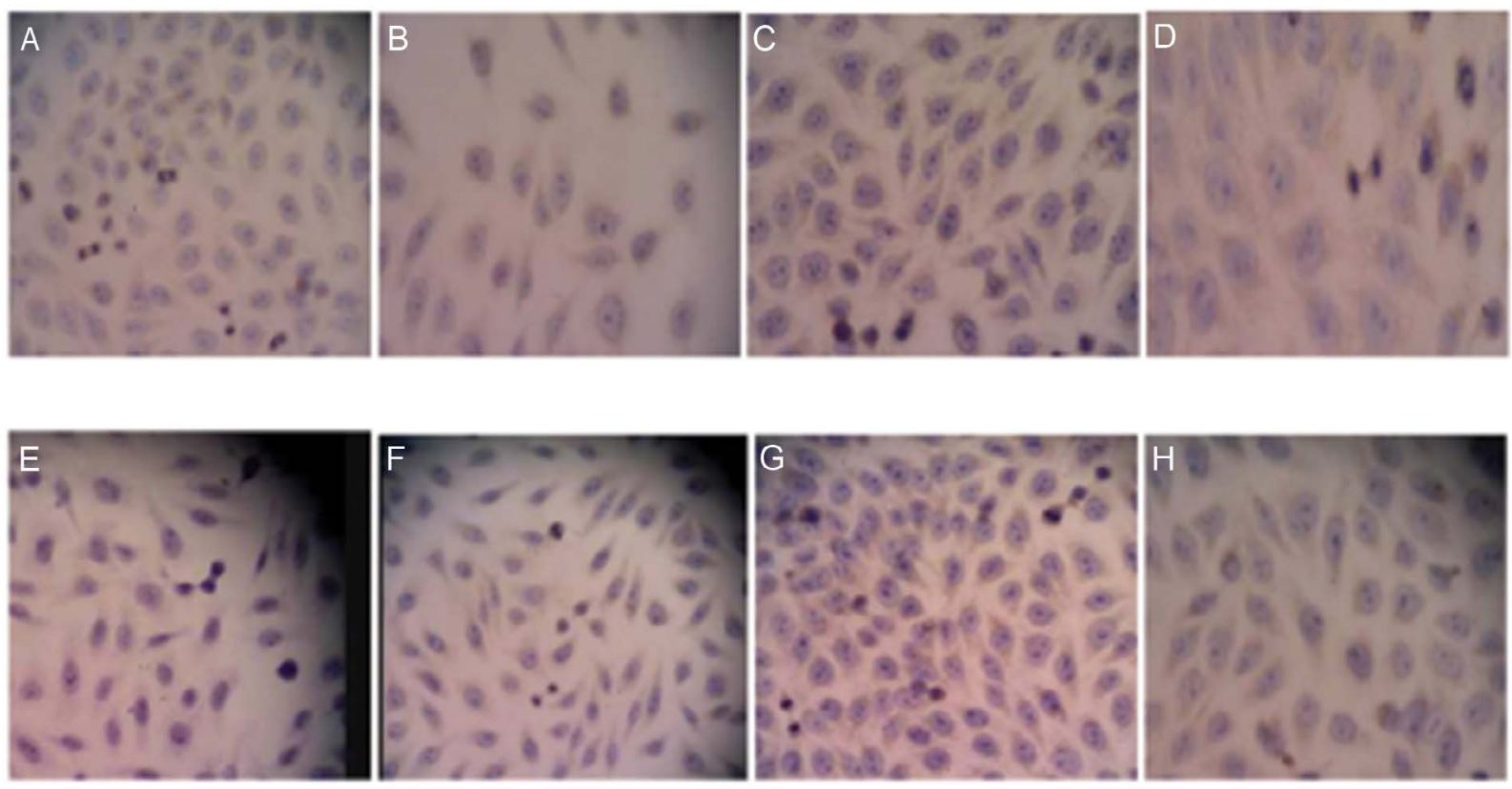

Figure 1. P53 Protein Expression: $A(C-G), B(Z Z 50-G), C(Z Z 100-G), D(Z Z 500-G) ; B c l 2$ Protein Expression: E (C-G), $F(Z Z 50-G)$, G (ZZ100-G), H (ZZ500-G).
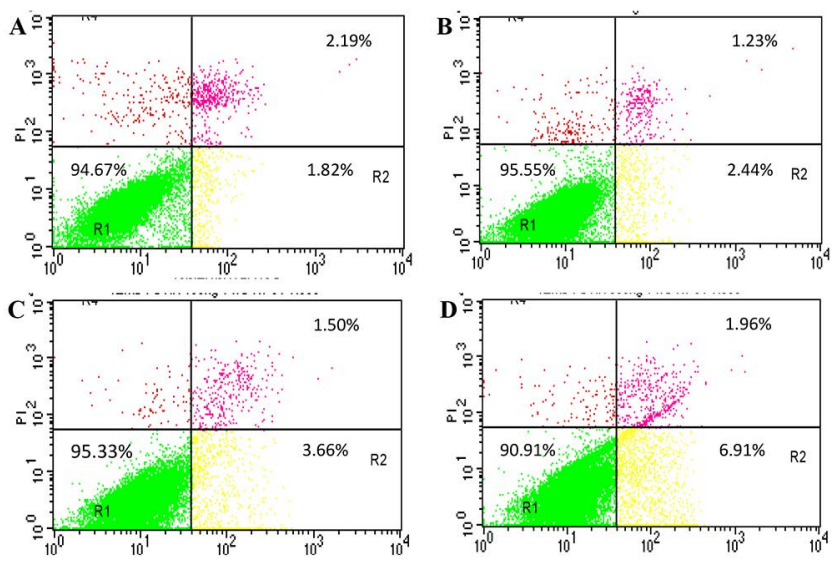

Figure 2. The Results of Annexin $V$ FLUOS test by Flow cytometry: Control group (A); ZZ50-G (B); ZZ100-G (C); ZZ500-G (D)

\subsection{Apoptotic Cells}

Mann Whitney analysis indicated that number of apoptotic cells in ZZ100-G and ZZ500-G were significant compared to that of $C-G(p<0.05)$. Similar result also occurred in ZZ100-G when compared to that of ZZ500-G $(\mathrm{p}<0.05)$ (Figure 3).

\subsection{P53 Protein Expression}

Mann Whitney analysis indicated that p53 protein expression in ZZ50-G and ZZ100-G were significant compared to that of $C-G(p<0.05)$. However, $p 53$ protein expression in ZZ500-G compared to that of $C-G$ was not significant $(\mathrm{p}>0.05)$ (Figure 3$)$.
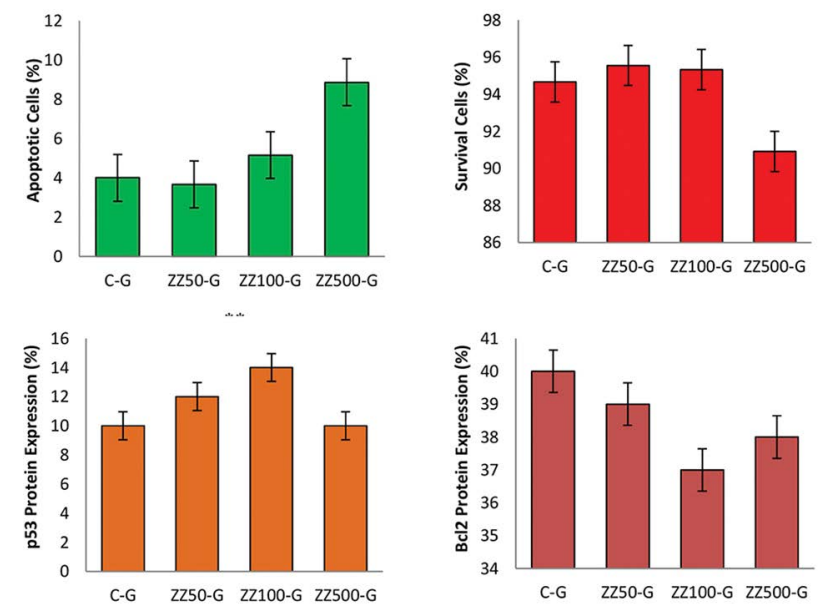

Figure 3. Mann Withney analysis on apoptotic cells and p53 Protein expression. Anova analysis on Bcl2 Protein expression: ${ }^{*} p<0.05 ;{ }^{* *} p>0.05$. 


\section{3 $\mathrm{Bcl} 2$ Protein Expression}

Post Hoc LSD analysis showed that $\mathrm{Bcl} 2$ protein expression in ZZ50-G, ZZ100-G, and ZZ500-G was significant when compared to that of $C-G(p<0.05)$. Similarily, Bcl2 protein expression in ZZ500-G was significant when compared to ZZ100-G and ZZ50-G $(\mathrm{p}<0.05)$ (Figure 3).

\section{Discussion}

The result of the present study indicated that zamzam water extract of CZ treatment on T47D cell culture was able to induce apoptosis particularly in the dose of 100 and $500 \mu \mathrm{g} / \mathrm{ml}$. However the apoptosis of T47D cells were very limited, less than $10 \%$, in contrary, the survival cells were majority, more than $90 \%$ (Figure 3 ). This result showed that the treatment of zamzam water extract of CZ on T47D cell line was not inducing apoptosis effectively. This result implied that zamzam water extract of CZ treatment by the dose of 100 and $500 \mu \mathrm{l}$ on T47D cell line was unable to trigger DNA damage largely and subsequently apoptosis.

In the biological system, apoptosis is used to delineate the intrinsic cell suicide program, and morphologically is characterized by global cell shrinkage, cell blabbing, and chromatin condensation accompanied by nuclear and DNA fragmentation into specific fragment sizes form DNA ladder pattern ${ }^{22}$. Initiation of apoptosis by the cell is determined by gene activities, leading to cellular self-destruction through either intrinsic or the extrinsic or both pathways ${ }^{23}$. DNA damage is initiators of apoptosis throughout process, by which wild type p53 in nucleus and cytoplasm may be activated and stabilized, which in turn serve as tumor suppressor function ${ }^{21}$. Consequently, activated p53 is able to drive intrinsic and extrinsic apoptotic pathway through amplifying the apoptotic signal consisting of apaf 1 , cell death receptor Fas (CD95), PUMA, Bax, Bak, and caspases ${ }^{23}$. On the other hand p53 mutant is missense mutation within the core domain, leading to the expression of a full-length mutant p53 protein, subsequently abrogate the tumor suppression function of wild type p53, and even gain new oncogenic activities to promote tumourigenesis ${ }^{21}$. When mutation at sequence of DNA specific binding domain containing serine residue occur result in p53 unable to bind $\mathrm{mdm}$. Moreover, $\mathrm{mdm} 2$ that serve as a protein anti p53 will be freed and activated leading to inhibition of p53 activity. Decrease in p53 activity is associated with the disappearance of the function of checkpoint control potency. Subsequently, the cell cycle does not stop in G1 phase (G1 arrest) in order to perform apoptosis, albeit p53 protein expression is increasing ${ }^{23}$. Consequently, mutated p53 is unable to bind DNA, induce p21 inactivity, and subsequently loss its capacity to regulates cell cycle and inhibit apoptosis cells ${ }^{21}$.

In the present study the T47D cells that underwent apoptosis were very limited, suggesting that treatment with zamzam water extract of CZ in 50,100 , and $500 \mu \mathrm{l}$ dosing were incapable of inducing DNA damage, activate and stabilizes p53 to trigger apoptosis. It was plausible, since T47D cells were used in this study constitute p53 mutant, accordingly lost its capacity to suppress tumor proliferation as reported ${ }^{21}$. In the present study, p53 expression in zamzam water extract of $\mathrm{CZ}$ treatment in 50,100 , and $100 \mu \mathrm{l}$ dosing were increasing significantly, indicating that treatment with $\mathrm{CZ}$ zamzam extract was able to induce $\mathrm{p} 53$ protein expression. However, due to its mutation the increase in p53 expression was not capable of inducing T47D cells apoptosis due to incapability of binding with DNA. The increase in p53 protein expression following $\mathrm{CZ}$ treatment, also suggested that CZ stimulate p53 protein expression at DNA level since controlling of $\mathrm{p} 53$ by $\mathrm{mdm}_{2}$ but not at DNA level, may be in protein level ${ }^{23}$. In contrary, $\mathrm{Bcl} 2$ protein expression following zamzam water extract of $\mathrm{CZ}$ treatment in the dose of 50,100 , and $500 \mu \mathrm{l}$ were decreased significantly, suggesting that $\mathrm{Bcl} 2$ protein could be down regulated. This result was similar to the study reported by Chen et al., (2013) that treatment with CZ essential oil decreased the levels of Bcl-2 and Bcl-xL and increased the ratio of $\mathrm{Bax} / \mathrm{Bcl}-2^{24}$.

According to phytochemical analysis, zamzam water extract of $\mathrm{CZ}$ contained flavonoids, phenol, and saponin and their concentration were lower compared to that of ethanolic extract of $\mathrm{CZ}^{18}$. The calculated $\mathrm{IC}_{50}$ value of CZ zamzam water extract was $28.24 \mathrm{pg} / \mathrm{ml}$ or $20 \mu \mathrm{g} / \mathrm{ml}$ slightly higher compared to that of ethanol extract of CZ $13.71 \mathrm{pg} / \mathrm{ml}$ or less than $20 \mu \mathrm{g} / \mathrm{ml}$. This study point out the $\mathrm{IC}_{50}$ value in zamzam water extract of $\mathrm{CZ}$ is defined as fairly active category, whereas the ethanol extract of $\mathrm{CZ}$ is defined as very active 
category ${ }^{25}$. Similarly, the study reported by Khaing et al., (2017) indicated that plain water extract of CZ posses strong inhibition with an $\mathrm{IC}_{50}$ value of $23.50 \mu \mathrm{g} /$ $\mathrm{ml}$ in the cell growth of cells metastatic ovarian cancer cells (SKOV3) in a time and dose-dependent manner ${ }^{26}$. Taken together, the effect of zamzam water extract of $\mathrm{CZ}$ on T47D apoptosis cell culture in order to be more effective need more doses of CZ.

\section{Conclusion}

Treatment of zamzam water extract of $\mathrm{CZ}$ with dose of $100 \mu \mathrm{l}$ on T47D cell line culture was capable of increasing the percentage number of apoptotic cells and 553 protein expression, but decreasing $\mathrm{Bcl} 2$ protein expression in T47D cell line culture. However the apoptotic cells were very limited less than $10 \%$.

\section{Acknowledgment}

The authors would like to thank the Magister Program of Biomedical Sciences Medical Faculty of Sultan Agung Islamic University for funding this study.

\section{Conflict of Interest}

The authors report no conflicts of interest. The authors alone are responsible for the content and writing of the paper.

\section{References}

1. Srivastava S, Somasagara RR, Hegde M, Nishana M, Tadi SK, Srivastava M, et al. Quercetin, a Natural Flavonoid Interacts with D NA, Arrests Cell Cycle and Causes Tumor Regression by Activating Mitochondrial Pathway of Apoptosis. Scientific Reports 2016; p. 1-13. https://doi.org/10.1038/srep24049.

2. Jnr FNG, Anyanful A, Eliason S, Adamu SM, Debrah S. Pattern of breast cancer distribution in ghana: a survey to enhance early detection, diagnosis, and treatment. International Journal of Breast Cancer. 2016; p. 1-9.

3. Chodidjah Widayati E, Taufiqurrachman Nasihun T. Treatment of Thyponium Flageliforme in Combination with Curcuma Zedoaria, and Phyllanthus Niruri Synergistically Enhances Apoptotic and Anti-Proliferative
Effect on Breast Cancer. Journal of Natural Remedies. 2017; p. 1-8. https://doi.org/10.18311/jnr/2017/8448.

4. Bombonati A, Sgroi DC. The molecular pathology of breast cancer progression. The Journal of Pathology. 2011; 223: 307-17. PMid:21125683 PMCid:PMC3069504. https://doi.org/10.1002/path.2808.

5. Jemal A, Siegel R, Ward E, Hao Y, Xu J, Murray T, Thun MJ. Cancer statistics, 2008. CA: A Cancer Journal for Clinicians. 2008; 58(2): 71-96. https://doi.org/10.1038/s41598-018-29308-7. PMid:18287387

6. Luo, X. et al. The role of targeting kinase activity by natural products in cancer chemoprevention and chemotherapy (Review). Oncology Report. 2015; 34: 547-54. https://doi.org/10.3892/or.2015.4029.

7. Zhang HW, Hu JJ, Fu RQ, Liu X, Zhang YH, Li J. Flavonoids inhibit cell proliferation and induce apoptosis and autophagy through downregulation of PI3K $\gamma$ mediated $\mathrm{PI} 3 \mathrm{~K} / \mathrm{AKT} / \mathrm{mTOR} / \mathrm{p} 70 \mathrm{S6K} / \mathrm{ULK}$ signaling pathway in human breast cancer cells. Scientific Reports. 2018; 8:11255. https://doi.org/10.1038/s41598-018-29308-7.

8. Hadisaputri YE, Miya zaki T, Suzuki S, Kubo N, Zuhrotun A, Yokobori T, et al. Molecular characterization of antitumor effects of the rhizome extract from Curcuma zedoaria on human esophageal carcinoma cells. International Journal of Oncology. 2015; 47: 2255-63. https://doi.org/10.3892/ijo.2015.3199 PMid:26498695

9. Peng CH, Chiu WT, Juan CW, Mau JL, Chen CC, Peng CC, Lai EY and Chyau CC: Pivotal role of curcuminoids on the antimutagenic activity of Curcuma zedoaria extracts. Drug and Chemical Toxicology. 2010; 33: 64-76. https://doi.org/10.3109/01480540903170738 PMid:19995306

10. Lakshmi S, Padmaja G, Remani P. Antitumour effects of isocurcumenol isolated from curcuma zedoaria rhizomes on human and murine cancer cells. International Journal of Medicinal Chemistry. 2011; 253962: 1-13. http://dx.doi.org/10.1155/2011/253962ＰMid:27429805 PMCid:PMC4939266

11. Rahman ASM, Wahab AN, Malek ASN. In vitro morphological assessment of apoptosis induced by anti proliferative constituents from the rhizomes of Curcuma zedoaria. Evidence-Based Complementary and Alternative Medicine. 2013; 257108: 1-14. http://dx.doi.org/10.1155/2013/257108 PMid:23762112 PMCid:PMC3671673

12. Meiyanto E, Hamid IS. Modulasi cyplal dan gstsertaekspresi p53 dan rassetelahinduksi 7,12-dimethyl 
Effect of Zamzam Water Extract of Curcuma zedoaria Treatment on Apoptosis, p53 and Bcl2 Protein Expression of T47D Cell Culture

benz $(\dot{\alpha})$ antrasen (dmba) dan pemberian anti karsinogenesisgynuraprocumbens dan curcuma zedoaria pada tikusgalurspraguedawley. Jurnal Penelitian Medika Eksakta. 2009; 8: 168-77.

13. Papademetrio DL, Trabucchi A, Cavaliere V, et al. The Cathechin flavonoid reduced proliferation and induced apoptosis of murine lymphoma cells LB02 through modulation of antiapoptotic proteins. Revista Brasileira de Farmacognosia. 2013; 23(3): 455-63. https://doi.org/10.1590/S0102-695X2013005000025

14. Alzeer J, Hadeed KA. Ethanol and its Halal status in food industries. Trends in Food Science \& Technology. 2016; 58: 14-20. https://doi.org/10.1016/j.tifs.2016.10.018

15. Nassini R, Andre E, Gazzieri D, Siena Gd, Zanas A, Geppetti P, Materazzi S. A Bicarbonate-Alkaline Mineral Water Protects from Ethanol-Induced Hemorrhagic Gastric Lesions in Mice. Biological and Pharmaceutical Bulletin. 2010; 33(8): 1319-23. https://doi.org/10.1248/bpb.33.1319 PMid:20686225

16. Bamosa A, Elnour A, Kaatabi H, Al Meheithif A, Aleissa $\mathrm{K}$, et al. Zamzam Water Ameliorates Oxidative Stress and Reduces Hemoglobin Alc in Type 2 Diabetic Patients. Journal of Diabetes and Metabolism. 2013; 4: 249. https://doi.org/10.4172/2155-6156.1000249

17. Shomar B. Zamzam water: Concentration of trace elements and othercharacteristics. Chemosphere.2012;86(6):600-5. https://doi.org/10.1016/j.chemosphere.2011.10.025 PMid:22138338

18. Hudaya I, Nasihun T, Sumarawati T. Effect of White Turmeric Extract (Curcuma zedoaria) Using Zam-zam Solvent Compare with Ethanol Solvent Against Breast Cancer CellT47D. Sains Medika. 2015; 6(2): 52-5.

19. Yu S, Kim T, Yoo KH, Kang K. The T47D cell line is an ideal experimental model to elucidate the progesterone-specific effects of a luminal A subtype of breast cancer. Biochemical and Biophysical Research Communications. 2017 May 6; 486(3): 752-8. https://doi.org/10.1016/j.bbrc.2017; 03.114
20. Deborah L Holliday and Valerie Speirs. Choosing the right cell line for breast cancer Research. Holliday and Speirs Breast Cancer Research. 2011; 13:215. https://doi.org/10.1186/bcr2889 PMid:21884641 PMCid:PMC3236329

21. Lim LY, Vidnovic N, Ellisen LW, Leong CO. Mutant p53 mediates survival of breast cancer cells. British Journal of Cancer. 2009; 101: 1606-12. https://doi.org// $10.1038 /$ sj.bjc.6605335 PMCid:PMC2778523

22. Widayati. E, Nasihun T. Treatment of Pimpinella Alpina Molk Improve Oxidative stress and Inhibit Liver Cellular Apoptosis in Rats Following UVB Irradiation: Is there Any Correlation? Bangladesh Journal of Medical Science. 2018; 17: 118-28. https://doi.org/10.3329/bjms.v17i1.35292

23. Taufiqurrachman. Decreased expression of caspase 3 in penis and prostate tissues of rat after the treatment with buceng (Pimpinella alpine Molk \& Euricoma longifolia Jack). Medical Journal of Indonesia. 2013; 22(1): 2-8. https://doi.org/10.13181/mji.v22i1.512

24. Chen CC, Chen Y, Hsi YT, Chang CS, Huang LF, Ho CT, Way TD, and Yie Kao JY. Chemical Constituents and Anticancer Activity of Curcuma zedoaria Roscoe Essential Oil against Non-Small Cell Lung Carcinoma Cells in Vitro and in Vivo. Journal of Agricultural and Food Chemistry. 2013; 61(47): 11418-27. https://doi.org/10.1021/jf4026184 PMid:24199734

25. Tanamatayarat P, Limtrakul P, Chunsakaow S, Duangrat C. Screening of some rubiaceous Plant for Cytotoxic Activity Against Cervix Carcinoma (KB-3-1) Cell line. Thai Journal of Pharmaceutical Sciences. 2003; 27(3-4): 167-72.

26. Khaing SL, Omar SZ, Loo CY, Arya A, Mohebali N, Mohd MA. Identification of active extracts of Curcuma zedoaria and their real- time cytotoxic activities on ovarian cancer cells and HUVEC cells. Biomedical Research. 2017; 28(21): 9182-7. 